\title{
Gaya Hidup Komsumtif Masyarakat Pengguna Jasa Koperasi Simpan Pinjam
}

(Studi pada Kelurahan Rabangodu Utara Kecamatan Raba Kota Bima)

\author{
${ }^{1}$ Marikar Mustakim, ${ }^{2}$ Buana Bima Fikri dan ${ }^{3}$ Azhar, \\ ${ }^{1}$ Mahasiswa Program Studi Pendidikan Sosiologi STKIP Bima \\ ${ }^{2,3}$ Program Studi Pendidikan Ekonomi STKIP Bima \\ Jalan Piere Tendean Kel. Mande Tlp.Fax (0374) 42801, Bima 84191, Indonesia \\ email; bimabuana212@gmail.com - azharstkipbima75@gmail.com
}

\begin{abstract}
Abstrak
Gaya hidup konsumtif pada bukan lagi hal baru ditengah kehidupan masyarakat, mulai dari penampilan, pakaian yang bermerek, make up yang mahal, warung makan bergengsi serta kendaraan yang digunakan, sangat diperhatikan mereknya sebagai simbol gaya hidup mereka. Dalam penelitian ini mendesklripsikan gaya hidup konsumtif pada masyarakat di Kota Bima. Penelitian ini adalah kualitatif deskriptif dengan menggunakan pendekatan kualitatif. Dengan 8 orang informan yang ditentukan secara purposive sampling. Tehnik pengumpulan data yakni observasi, wawancara dan dokumentasi. Data yang didapatkan di lapangan di analisis dengan cara reduksi data, display data, dan verifikasi data. Pengujian keabsahan data menggunakan triangulasi tehnik pengumpulan data, triangulasi sumber data, dan triangulasi waktu. Adapun teori yang digunakan dalam penelitian ini adalah teori konsumsi Franco Modegliani (19501962).Hasil temuan dalam penelitian ini, mengambarkan bahwa pengguna jasa koperasi simpan pinjam memiliki berbagai model gaya hidup konsumtif seperti membeli baju, tas, sepatu, aksesoris, android secara onlinedan tempat yang bertaraf gengsi, warung makan yang menjadi langgananya harus mewah, dengan tujuan untuk mempertahankan status dan penampilannya, padahal uang yang digunakan adalah bukan uang sendiri. Dampak negatif dari perilaku tersebut adalah adanya sifat boros, pelanggang nasabah lebih dari 2 sampai 3 koperasi, selain itu nasabah koperasi menjadi malas bekerja dan berusaha, kemudian untuk membayar cicilan koperas dibayar dengan menjadi nasabah lagi di koperasi yang lainnya malas mencari penghasilan serta adanya kecemburuan sosial serta adanya pengguna yang meminjam lebih dari satu kantor koperasi. Dampak positif dari perilaku tersebut hampir rata-rata tidak ditemukan sama sekali.
\end{abstract}

Kata Kunci : Gaya Hidup Konsumtif, Koperasi Simpan Pinjam. 


\section{Pendahuluan}

Kota Bima merupakan salah satu dari sekian banyak wilayah yang ada di Indonesia khususnya Nusa Tenggara Barat. Meskidikenalsebagaikotaotonomtetapimasy arakat Kota Bima selalu mengikuti perkembangan zaman, baik dari segi lifestyle maupunperkembangan $\mathrm{di}$ bidanglainnya. Kehidupan yang semakin modern membuatmasyarakat dari golongan yang muda hinggagolongan yang tua, antusias terhadap adanya hal-hal baru sehingga tercipta gaya hidup konsumtif.

Konsumtif ditandai oleh adanya kehidupan mewah dan berlebihan. Penggunaaan segala hal yang dianggap paling mahal yang memberikan kepuasan dan kenyamanan fisik sebesar besarnya serta adanya pola hidup manusia yang dikendalikan dan didorong oleh semua keinginan untuk memenuhi hasrat kesenangan semata-mata. Hal ini diperkuat oleh Anggasari yang mengatakan bahwa perilaku konsumtif di tandai dengan tindakan membeli barang-barang yang kurang atau tidak diperhitungkan sehingga sifatnmya menjadi berlebihan.

Biasanya, perilaku konsumtif digeluti oleh orang-orang yang berada di kelas menengah (middle class) dan kelas atas (upper class), yang pada umunya ditunjukkan sebagai bentuk ekspresi diri dalam menarik perhatian, karena berharap hadiah yang ditawarkan jika membeli barang tersebut, karena produk atau barang tersebut menarik, karena harga yang ditawarkan sangat murah meskipun tidak terlalu bermanfaat. Meskipun perilaku konsumtif umunya digeluti oleh golongan middle class maupun upper class. Namun, dalam perkembangannya hingga kini justru perilaku konsumtif tidak hanya dicirikan oleh orang-orang yang berada pada golongan middle class maupun upper class, melainkan masyarakat yang memiliki latar belakang perekonomian rendah memiliki perilaku konsumtif. Sehingga apabila dilihat dari segi penampilan sangat sulit membedakan antara masyarakat yang memiliki latar belakang perekonomian yang kurang, masyarakat yang memiliki latar belakang perekonomian menengah, maupun masyarakat yang memiliki latar belakang ekonomi yang tinggi.

Perilaku tersebut telah merambat menjadi suatu kebiasaan. Hal tersebutterjadiakibat kurangnya pemahaman masyarakat terkait perbedaan antara keinginan dan kebutuhan. Sehingga, membuat daya konsumtif semakin meningkat.

Perilaku konsumtif yang terjadi pada kebanyakan masyarakat Kelurahan Rabangodu Utara Kecamatan Raba yaitu 
mereka menggunakan jasa koperasi simpan pinjam dengan cenderung bersikap seperti orang yang berada pada kelas atas (upper class). Hal tersebut secara umum dilakukan dengan tujuan agar dapat dipuji oleh masyarakat lainnya. Padahal jika ditinjau jasa koperasi simpan pinjam seharusnya digunakan untuk memenuhi kebutuhan hidup sehari-hari. Namun berbeda halnya bagi masyarakat Kelurahan Rabangodu Utara yang cenderung menggunakan jasa koperasi simpan pinjam bukan untuk memenuhi kebutuhanhidup sehari-hari atau untuk kepentingan usaha melainkan untuk hidup mewah layaknya masyarakat yang berada di kelas atas. Misalnya, mendatangi tempat makan sepertiKFC atau Rocket Chicken, secara sering namun bukan semata-mata bertujuan untuk menikmati makanan yang ditawarkan melainkan sekedar datang demi mendapatkan background foto yang nantinya dapat dipamer di media sosial, mendatangi cafe 23 kali dalam seminggu, mengoleksi produk atau barang seperti tas, sepatu, aksesoris, berpakaian yang berlebihan dan bermerek dalam hal ini membeli baju yang kekinian atau keluaran terbaru.

Pada dasarnya membeli sesuatu memang hak setiap orang bahkan hak tersebut tidak dapat dibatasi sepanjang tidak melanggar hak orang lain, tidak melanggar undang-undang, tidak melanggar kesusilaan maupun ketertiban umum. Tetapi meskipun setiap orang memiliki hak untuk mengekspresikan diri. Namun dalam hal ini, kebanyakan masyarakat Kelurahan Rabangodu Utara justru melakukan peminjaman dengan mengatasnamakan kepentingan modal usaha tetapi yang terjadi justru sebaliknya. Sehingga hal tersebut menunjukkan adanya ketidaksesuaian antara teori dengan praktik. Selain menggunakan jasa koperasi simpan pinjam demi terpenuhinya keinginan, sebagian besar masyarakat Kelurahan Rabangodu Utara juga menggunakan kredit dari Bank.

\section{Tinjauan Pustaka}

\section{Gaya Hidup Komsumtif}

Gaya hidup merupakan ciri sebuah Negara modern, atau yang biasa disebut dengan modernitas. Maksudnya adalah siapapun yang hidup dalam masyarakat modern akan menggunakan gagasan tentang gaya hidup untuk menggabarkan tindakan sendiri atau orang lain (Mario Ferdy Pradana, 2013:5),

Gaya hidup adalah suatu perilaku yang ditandai oleh adanya kehidupan mewah dan berlebihan. Perilaku konsumtif juga dapat ditunjukkan dalam penggunaan segala hal yang dianggap paling mahal yang memberikan kepuasan dan kenyamanan fisik sebesarbesarnya. Perilaku konsumtif juga 
menggambarkan adanya pola hidup manusia yang dikendalikan dan didorong oleh suatu keinginan untuk memenuhi hasrat kesenangan semata-mata (Mario Ferdy Pradana, 2013:5). Maka dari itu gaya hidup merupakan pola-pola tindakan yang membedakan antara satu orang dengan orang yang lain. Dalam interaksi sehari hari kita bisa menerapkan suatu gagasan tentang gaya hidup tanpa perlu menjelaskan apa yang dimaksud (Mario Ferdy Pradana, 2013:5-6).

\section{Karakteristik Gaya Hidup Konsumtif}

Adapun karakteristik perilaku konsumtif menurut Mario Ferdy Pradana, (2013) adalah

a. Membeli produk karena iming-iming hadiah. Pembelian barang tidak lagi melihat manfaatnya akan tetapi tujuanya hanya untuk mendapatkan hadiah yang ditawarkan.

b. Membeli produk karena kemasanya menarik. Seseorang tertarik utuk membeli suatu barang karena kemasanya yang berbeda dari yang lainya. Kemasan suatu barang yang menarik dan unik akan membuat seseorang membeli produk tersebut.

c. Membeli produk demi menjaga penampilan gengsi. Gengsi membuat seseorang lebih memilih membeli barang yang dianggap dapat menjaga penampilan diri, dibandingkan dengan membeli barang lain yang lebih dibutuhkan.

d. Membeli produk berdasarkan pertimbangan harga (bukan atas dasar manfaat). Konsumen cenderung berperilaku yang ditindakan oleh adanya kehidupan mewah sehingga cenderung menggunakan segala hal yang dianggap paling mewah.

e. Membeli produk hanya sekedar menjaga simbol atau status. Seseorang menganggap barang yang digunakan adalah suatu simbol dari statusnya. Dengan membeli suatu produk dapat memberikan simbol status agar kelihatan lebih keren dimata orang lain.

f. Memakai produk karena unsur konformitas terhadap model yang mengiklankan produk. Seseorang memakai sebuah barang karena tertarik untuk bisa menjadi seperti moel iklan tersebut ataupun karena model yang diiklankan adalah seorang idola dari pembeli

\section{Faktor-Faktor Penyebab Gaya Hidup Konsumtif}

Menurut (Bagong Suyatno 2007: 159), perilaku konsumtif dipengaruhi oleh empat faktor, yaitu terdiri dari faktor-faktor budaya, sosial, pribadi, dan psikologi. 


\section{Dampak Gaya Hidup Konsumtif}

Adapun dampak dari gaya hidup komsumtif yaitu dampak positif dan dampak negatif

a. Dampak Negatif

Gaya hidup konsumtif jika dilihat dari sisi negatifnya akan memberikan sebuah dampak (Kanuk, L.L, 2004:32-33).

1) Pola hidup yang boros dan akan menimbulkan kecemburuan sosial, karena orang akan membeli semua barang yang diinginkan tanpa memikirkan harga barang tersebut murah atau mahal, barang tersebut diperlukan atau tidak, sehingga bagi orang yang tidak mampu mereka tidak akan sanggup untuk mengikuti pola kehidupan yang seperti itu.

2) Mengurangi kesempatan untuk menabung, karena orang akan lebih banyak membelanjakan uangnya dibandingkan menyisihkan untuk ditabung.

3) Cenderung tidak memikirkan kebutuhan yang akan datang, orang akan mengkonsumsi lebih banyak barang pada saat sekarang tanpa berpikir kebutuhannya di masa datang.

b. Dampak Positif
Gaya hidup konsumtif jika dilihat dari sisi positifnya akan memberikan sebuah dampak

a. Membuka dan menambah lapangan pekerjaan, karena akan membutuhkan tenaga kerja lebih banyak untuk memproduksi barang dalam jumlah besar.

b. Meningkatkan motivasi konsumen untuk menambah jumlah penghasilan, karena konsumen akan berusaha menambah penghasilan agar bisa membeli barang yang diinginkan dalam jumlah dan jenis yang beraneka ragam.

c. Menciptakan pasar bagi produsen, karena bertambahnya jumlah barang yang dikonsumsi masyarakat maka produsen akan membuka pasar-pasar baru guna mempermudah memberikan pelayanan kepada masyarakat (kanuk, 1.1, 2004:32-33).

\section{Metode Penelitian}

penelitian ini adalah kualitatif deskriptif dengan menggunakan pendekatan kualitatif. Dengan 8 orang informan yang ditentukan secara purposive sampling. Tehnik pengumpulan data yakni observasi, wawancara dan dokumentasi. Data yang didapatkan di lapangan di analisis dengan 
cara reduksi data, display data, dan verifikasi data. Pengujian keabsahan data menggunakan triangulasi tehnik pengumpulan data, triangulasi sumber data, dan triangulasi waktu. Adapun teori yang digunakan dalam penelitian ini adalah teori konsumsi Franco Modegliani (1950-1962

\section{Pembahasan}

Perilaku konsumtif merupakan suatu perilaku membeli dan menggunakan barang yang tidak didasarkan pada pertimbangan yang rasional dan memiliki kecenderungan untuk mengkonsumsi sesuatu tanpa batas dimana individu lebih mementingkan faktor keinginan daripada kebutuhan serta ditandai oleh adanya kehidupan mewah dan berlebihan, penggunaan segala hal yang paling mewah yang memberikan kepuasan dan kenyamanan fisik (Mario Ferdy Pradana, 2013:6).Perilaku konsumtif inilah yang merupakan suatu perilaku yang dimiliki oleh pengguna jasa koperasi simpan di Kelurahan Rabangodu Utara.

Peneliti menilai bahwa pengguna jasa koperasi simpan pinjam di Kelurahan Rabangodu Utara memiliki gaya hidup yang konsumtif, hal ini dapat dilihat dari banyaknya masyarakat yang menggunakan jasa koperasi simpan pinjam demi memenuhi keinginannya. Masyarakat pengguna jasa koperasi simpan pinjam di Kelurahan Rabangodu Utara memiliki gaya konsumtif yang berbeda-beda ada yang cenderung berbelanja berlebihan dari segi pakaian, tas, sepatu, aksesoris, android, dan ada pula yang konsumtif dari segi belanja paket internet.

Perilaku konsumtif masyarakat pengguna jasa koperasi simpan pinjam di Kelurahan Rabangodu Utara dipengaruhi oleh berbagai faktor seperti faktor ekonomi, faktor lingkungan, faktor usia, serta adanya pengaruh media sosial. Dalam hal ekonomi, semakin tinggi perekonomian seseorang semakin tinggi pula perilaku konsumtif yang dimiliki bahkan secara umum di lingkungan masyarakat khususnya di Kelurahan Rabangodu Utara perilaku konsumtif bukan hanya dimiliki oleh masyarakat yang memiliki perekonomian yang tinggi, tetapi masyarakat yang memiliki perekonomian yang kurang juga memiliki perilaku konsumtif yang tinggi. Hal tersebut dapat dilihat dari banyaknya masyarakat yang menggunakan jasa koperasi simpan pinjam.

Perilaku konsumtif yang dipengaruhi oleh faktor lingkungan ialah karena kebanyakan masyarakat di Kelurahan Rabangodu Utara melihat perkembangan yang terjadi di lingkungan sekitarnya terutama karena adanya kelompokkelompok tertentu yang mendorong seseorang untuk berbelanja secara berlebihan. Mengenai faktor usia, di Kelurahan Rabangodu Utara perilaku 
konsumtif bukan hanya dimiliki oleh orang yang masih berusia muda, tetapi termasuk orang yang berada di usia menengah maupun usia tua, dan tingkatan gaya konsumtif dalam usia inilah yang berbedabeda. Kemudian terkait dengan pengaruh perilaku konsumtif yang disebabkan oleh pengaruh media sosial secara umum ialah karena banyaknya tawaran-tawaran menarik di media sosial serta kemudahan belanja secara online .

Perilaku konsumtif yang dipengaruhi oleh berbagai faktor memiliki dampak terhadap masyarakat yang memiliki perilaku tersebut.Dampak positif perilaku ini salah satunya adalah meningkatkan kepercayaan diri. Sedangkan dampak negatifnya ialah sulitdalam mengontrol perekonomian.

Perilaku konsumtif masyarakat di Kelurahan Rabangodu Utara dikaitkan dengan teori konsumsi Franco Modigliani maka berdasarkan teori yang dikemukakan oleh Franco Modigliani bahwa pola pengeluaran konsumsi masyarakat mendasarkan kepada kenyataan bahwa pola penerimaan dan pola pengeluaran konsumsi seseorang pada umumnya dipengaruhi oleh masa dalam siklus hidupnya.Karena orang cenderung menerima penghasilan/pendapatan yang rendah pada usia muda, tinggi pada usia menengah dan rendah pada usia tua, maka rasio tabungan akan berfluktuasi sejalan dengan perkembangan umur mereka yaitu orang muda akan mempunyai tabungan negatif (dissaving), orang berumur menengah menabung dan membayar kembali pinjaman pada masa muda mereka, dan orang usia tua akan mengambil tabungan yang dibuatnya di masa usia menengah(Sofyan Syahnur dkk, 2014:14). Teori ini sangat sesuai dengan kenyataan yang terjadi pada pengguna jasa koperasi simpan pinjam masyarakat Kelurahan Rabangodu Utara Kecamatan Raba Kota Bima

Masyarakat pengguna jasa koperasi simpan pinjam berada pada usia muda dan usia menengah, masyarakat yang berada pada usia 21tahun dan 23 tahun merupakan masyarakat yang berusia muda. Sedangkan yang berumur 26 tahun, 34 tahun, 39 tahun, dan 45 tahun merupakan masyarakat yang berusia menengah. Usia dari masingmasing masyarakat tersebut merupakan usia produktif, sedangkan definisi kelompok usia produktif berdasarkan Badan Pusat Statistik ialah mereka yang berada pada rentan usia 15 sampai 64 tahun.

Masyarakat yang berumur tua tidak ada yang melakukan pinjaman di kantor jasa koperasi simpan pinjam. Meski demikian, masarakat yang berumur tua tersebut juga memiliki perilaku konsumtif. Sehingga ini menunjukkan kesesuaian 
antara teori Franco Modigliani dengan hasil penelitian penulis bahwa di usia muda masyarakat memiliki pendapatan yang sedikit, di usia menengah membayar kembali hutang yang dipinjam pada usia muda dan menabung untuk masa tua, dan di usia tua mengambil tabungan yang telah disiapkan di usia menengah. Hal tersebut sangat sesuai dengan keadaan masyarakat pengguna jasa koperasi simpan pinjam di Kelurahan Rabangodu Utara, bahwa masyarakat pada usia muda melakukan peminjaman demi memenuhi keinginannya, begitupun masyarakat yang berusia menengah, tetapi bagi masyarakat di usia tua tidak lagi melakukan peminjaman tetapi justru menggunakan tabungan yang telah disiapkan di usia menengah. Namun pada masyarakat yang berada pada usia tua ini kepentingan-kepentingan seperti belanja bukan hanya untuk kepentingan pribadi melainkan juga untuk kepentingan anakanaknya, selain itu meskipun usia seseorang merupakan faktor penentu perilaku konsumtifnya, pendapatan atau kekayaan juga merupakan penyebab dari adanya perilaku konsumtif, semakin tinggi perekonomian seseorang semakin tinggi pula perilaku konsumtif yang dimiliki.

Masyarakat pengguna jasa koperasi simpan pinjam yang berusia muda memang memiliki pendapatan yang sedikit, dan karena sedikitnya jumlah pendapatan yang dimiliki sehingga melakukan pinjaman di kantor jasa koperasi simpan pinjam. Hal tersebut dilakukan agar mampu memenuhi keinginan untuk membeli sesuatu seperti baju, tas, sepatu, aksesoris, Android, serta banyaknya anak di usia muda yang lebih senang nongkrong dan makan di tempattempat mewah. Penyebab dari adanya perilaku konsumtif di Kelurahan Rabangodu Utara Kecamatan Raba Kota Bima ini ialah karena pada usia muda seseorang cenderung memiliki pendapatan yang sedikit sedangkan pengaruh lainnya yaitu faktor ekonomi, faktor lingkungan, pengaruh media sosial, serta pengaruh usia yang pada usia muda masih cenderung labil sehingga mengikuti apa yang diinginkan. Dampak dari adanya perilaku konsumtif pada usia muda ialah pada usia menengah masyarakat harus membayar hutang-hutang yang telah diambil pada usia muda sehingga tabungan untuk masa depan akan berkurang dan inilah yang terjadi pada pengguna jasa koperasi simpan pinjam di kelurahan Rabangodu Utara Kecamatan Raba Kota Bima. Sedangkan dampak positif yang didapatkan pengguna jasa koperasi simpan pinjam yang berada pada usia muda ialah memiliki tingkat percaya diri yang tinggi, memotivasi untuk bekerja lebih keras dan berpenghasilan lebih banyak, terbukanya lapangan pekerjaan, serta kurangnya angka penggangguran. 
Teori Franco Modegliani pada usia menengah seseorang akan menabung dan membayar hutang pada usia muda, hal ini sangat sejalan dengan hasil penelitian peneliti di Kelurahan Rabangodu Utara Kecamatan Raba Kota Bima bahwa masyarakat pengguna jasa koperasi simpan pinjam melakukan pinjaman untuk membayar hutang sekaligus mempersiapkan tabungan, hal tersebut dapat dilihat dari adanya masyarakat yang menggunakan jasa koperasi simpan pinjam untuk kepentingan modal usaha, tetapi disamping untuk kepentingan modal usaha, kebanyakan masyarakat menggunakan jasa koperasi simpan pinjam untuk memenuhi keinginan dalam kehidupan sehari-hari seperti membeli baju, tas, serta produkproduk lain yang bermerek. Pada usia menengah faktor yang mempengaruhi perilaku konsumtif seseorang ialah selain karena usianya, juga dipengaruhi oleh faktor ekonomi, faktor lingkungan dan pengaruh media sosial.Dalam hal ekonomi semakin tinggi perekonomian seseorang semakin tinggi pula perilaku konsumtif yang dimiliki hal ini sesuai dengan yang dikatakan oleh Franco Modigliani bahwa kekayaan juga merupakan penentu tingkah laku konsumsi, konsumsi akan meningkat jika nilai kekayaan naik. Adapun dampak perilaku konsumtif pada masyarakat yang berada di usia menengah ialah perilaku boros tersebut sulit dikontrol, adanya kecemburuan sosial bagi masyarakat lain, memunculkan rasa kurang percaya diri ketika tidak mampu memiliki sesuatu yang dimiliki oleh orang-orang disekitar, serta tabungan yang dipersiapkan di usia tua jumlahnya sedikit. Sedangkan dampak positif perilaku konsumtif masyarakat pada usia menengah ialah memiliki rasa percaya diri ketika mampu memenuhi keinginan, terbukanya lapangan pekerjaan akibat semakin banyaknya jumlah permintaan barang, dan mengurangi angka pengangguran.

Perilaku konsumtif pada usia tua terjadi akibat adanya kekayaan yang telah dipersiapkan di masa usia menengah, sehingga pada usia tua kebanyakan masyarakat sekalipun memiliki pendapatan yang sedikit tetapi tetap saja memiliki perilaku konsumtif seperti berbelanja secara berlebihan dalam hal pakaian, tas, sepatu, termasuk paket internet. Tetapi di usia tua umumnya adanya perilaku konsumtif tersebut seperti berbelanja tas, sepatu, maupun produk lainnya, tidak serta merta untuk kepentingan pribadi saja, tetapi pada usia tua biasanya seseorang berbelanja berlebihan untuk kepentingan anakanaknya. Faktor yang mempengaruhi perilaku konsumtif tersebut ialah karena pada hakikatnya seseorang yang berada pada usia tua cenderung memikirkan 
kepentingan anak-anaknya dan karena telah disiapkannya tabungan di masa tua tersebut sehingga bebas untuk berbelanja. Dampak dari perilaku konsumtif pada usia tua ini ialah kurangnya tabungan untuk kehidupan anak di masa depan, serta adanya kecemburuan sosial.

Perilaku konsumtif pengguna jasa koperasi simpan pinjam di Kelurahan Rabngodu Utara dipengaruhi oleh faktor usia, serta faktor lain seperti faktor ekonomi, faktor lingkungan, maupun pengaruh media sosial dan ini sesuai dengan teori Franco Modigiani.

\section{Kesimpulan}

Pengguna jasa koperasi simpan simpan di Kelurahan Rabangodu Utara adalah pengguna yang berusia muda dan berusia menengah. Sedangkan bentukbentuk dari perilaku konsumtif yang dimiliki oleh masyarakat di Kelurahan Rabangodu Utara khususnya bagi pengguna jasa koperasi simpan pinjam ialah berbelanja secara berlebihan dalam hal ini seperti baju, tas, rok, sepatu, aksesoris, android, maupun produk-produk lain yang bermerek maupun produk yang mahal.

Perilaku konsumtif yang dimiliki oleh masyarakat pengguna jasa koperasi simpan disebabkan oleh beberapa faktor seperti faktor usia, faktor ekonomi, faktor lingkungan, serta pengaruh media sosial, dan semakin mudahnya berbelanja.

Adapun mengenai dampak dari perilaku konsumtif yang dialami oleh masyarakat pengguna jasa koperasi simpan pinjam di Kelurahan Rabangodu Utara adalah semakin terbukanya lapangan pekerjaan akibat banyaknya permintaan barang di perusahaan, kurangnya angka pengangguran akibat dibukanya lapangan pekerjaan, meningkatnya motivasi untuk berbelanja dan berpenghasilan lebih banyak agar mampu membeli apapun yang diinginkan, serta meningkatnya rasa percaya diri. Sedangkan dampak negatif perilaku konsumtif yang dialami oleh masyarakat pengguna jasa koperasi simpan pinjam adalah sulitnya mengontrol sifat boros, kurangnya rasa percaya diri ketika tidak mampu memiliki sesuatu seperti yang dimiliki oleh orang-orang disekitar, adanya kecemburuan sosial, serta kurangnya tabungan untuk masa depan.

\section{Daftar Pustaka}

Bagong. (2007)Sosiologi teks pengantar dan terapan. Jakarta: Kencana prenadanmedia group.

Kanuk, L.L, (2004). Perilaku Konsumen, (Jakarta: PT Indeks Group Gramedia,

Khadijah.(2013) . Studi Hubungan Kerja Masyarakat Nelayan Kelurahan Ponjalae, Kecamatan Wara Timur Kota Palopostudy Public Work Relation Fisherman Farmers Ofponjalae, East Wara Districpalopo 
City. Makassar : Universtas Hasanuddin.

Mario Ferdy Pradana. (2013). Gaya Hidup Komsumtif Pada Mahasiswa. Universitas Muhammadiyah Malang.

M. Saripuddin. (2019). Hubungan Kenakalan Remaja Dengan Fungsi Sosial Keluarga. Yogyakarta

:Universitas Islam Negeri Sunan Kalijaga.

Muhammad Afdhal, Sofyan Syahnur Dkk. 2014. Konsumsi Di Provinsi Aceh. Universitas Syiah Kuala.

Moleong, Lexy. J. 2009.Metode Penelitian Kualitatif (Bandung: PT. Remaja Rosdakarya.

Pupu Saeful Rahmat. (2009). Penelitian Kualitatif (Versielektronik).Jurnal Equilibrium5(9):1-8. Diperoleh 16 Mei 2020

Sugiyono. (2011). Metode Penelitian Kuantitatif, Kualitatif dan $R \& D$. Bandung: Afabeta.

Sugiyono. (2007). Metode Penelitian Kuantitatif Kualitatif dan $R \& D$. Bandung: Elfabeta.

Sukandarumidi. 2002. Metode Penelitian. Yogyakarta : Universitas Gadjah Mada

Sofyan Syahnur. 2015. Analisis FaktorFaktor Yang Mempengaruhi Tingkat Pengangguran Di Aceh. Jurnal Ilmu Ekonomi Pascasarjana Universitas Syiah Kuala, Volume 3.

Tjutju Soendari. Diperoleh 25 Mei 2020 darihttp://file.upi.edu/Direktori /FIP /JUR._PEND._LUAR_BIASA/19560 2141980032TJUTJU_SOENDARI/Po wer_Point_Perkuliahan/Penelitian_P KKh/Keabsahan_data.ppt_\%5BComp atibility_Mode\%5D.pdf.

Yudi Triyanto. (2011). Tinjauan Hukum Terhadap Pelaksanaan Perjanjian Pinjaman Koperasi Primadana Cabang Semarang. Semarang : Universitas Stikubank Semarang. 